\title{
Glomerulocystic kidney disease
}

\author{
John J. Bissler • Brian J. Siroky • Hong Yin
}

Received: 30 July 2009 /Revised: 23 November 2009 / Accepted: 26 November 2009/Published online: 21 January 2010

(C) IPNA 2010

\begin{abstract}
Glomerulocystic disease is a rare renal cystic disease with a long descriptive history. Findings from recent studies have significantly advanced the pathophysiological understanding of the disease processes leading to this peculiar phenotype. Many genetic syndromes associated with glomerulocystic disease have had their respective proteins localized to primary cilia or centrosomes. Transcriptional control of renal developmental pathways is dysregulated in obstructive diseases that also lead to glomerulocystic disease, emphasizing the importance of transcriptional choreography between renal development and renal cystic disease.
\end{abstract}

Keywords Basal body $\cdot$ Cilia - Glomerulocystic kidney disease $\cdot$ Polycystic kidney disease .

Tuberous sclerosis complex

\section{Introduction}

Although glomerulocystic kidney disease is somewhat rare, it is far from a new entity. As early as 1941, Roos described an infant with failure to thrive, rickets, and renal failure associated with cystic glomeruli [1]. Approximately 20 years later, Bialestock used microdissection to further

\footnotetext{
J. J. Bissler $(\bowtie) \cdot$ B. J. Siroky

Division of Nephrology and Hypertension,

Cincinnati Children's Hospital Medical Center,

MLC 7022, 3333 Burnet Avenue,

Cincinnati, OH 45229-3039, USA

e-mail: john.bissler@cchmc.org

H. Yin

Division of Pathology,

Cincinnati Children's Hospital Medical Center,

Cincinnati, OH 45229-3039, USA
}

characterize glomerular cysts associated with renal dysplasia and failure in an infant [2]. Baxter noted that glomerulocystic kidney disease could be limited to the cortex or be associated with medullary cysts [3], while Taxy and Filmer first used the term 'glomerulocystic kidney disease' to describe this dilatation of Bowman's space [4]. Bernstein added significant clarity to the diagnoses by defining the glomerular cyst as the dilatation of Bowman's space in the plane of section of two- to threefold that of normal [5]. Furthermore, he used the occurrence of glomerular tufts, within at least $5 \%$ of otherwise identifiable cysts, as being consistent with the diagnosis of glomerulocystic kidney and, like Baxter, he did not exclude associated tubular dilatations or cysts. Bernstein originally classified glomerulocystic kidney disease into three categories: (1) glomerulocystic kidney disease comprising nonsyndromal inheritable and sporadic forms of severely cystic kidneys in children and adults, (2) glomerulocystic kidneys associated with inheritable malformation syndromes, and (3) glomerular cysts in dysplastic kidneys [5]. His work served as the basis for a working descriptive classification of glomerulocystic disease (Table 1) [6]. Recent scientific progress offers new insight into the pathobiology of glomerulocystic disease and builds upon the Bernstein classification. A greater understanding of the developmental and genetic pathobiology of glomerulocystic disease will likely refine the classification system and may also reveal new therapeutic targets.

\section{Inherited and syndromic forms of glomerulocystic kidney disease}

In describing glomerulocystic kidney disease, Bernstein noted that many patients had a family history of autosomal 
Table 1 Classification of glomerulocystic disease

Classifications of
glomerulocystic kidney disease

Familial nonsyndromic

Associated with inheritable malformation syndromes

Syndromic, non-Mendelian

Sporadic polycystic kidney disease in young infants

Tuberous sclerosis complex

Acquired and dysplastic kidneys

New mutations

Hemolytic uremic syndrome and obstructive uropathy

dominant polycystic kidney disease (Fig. 1). He based the diagnosis of glomerulocystic kidney disease on anatomical findings and did not distinguish between familial and sporadic disease, in part because of the possibility of new mutations in known polycystic disease loci. The autosomal dominant inheritance of glomerulocystic kidney disease is well documented in the literature and can be associated with autosomal dominant polycystic kidney disease (ADPKD) genes [7]. An autosomal dominant glomerulocystic kidney disease that is not linked to the autosomal dominant polycystic kidney disease genes (PKD1 and $P K D 2$ ) or the human homolog of mouse jcpk locus also exists [8]. While the presentation of glomerulocystic kidney disease is more common in newborns and young children, it also occurs in older children and adults. A developmental aspect of renal cystic disease has recently been identified, and it is possible that the glomerulocystic kidney disease phenotypic may manifest because of developmental timing and the effects of specific mutations [9, 10]. These effects may hinge on cell proliferation during organogenesis that then slow but which can then increase again following acute renal injury [11]. Glomerulocystic kidney disease also can be found in patients diagnosed with other identifiable diseases, such as tuberous sclerosis complex, medullary cystic kidney disease, Jeune syndrome, nephronophthisis, Meckel-Gruber syndrome (Fig. 2), orofaciodigital syndrome, brachymesomelia-renal syndrome, trisomy 9 , 13, and 18 , the short rib-polydactyly syndromes, and Zellweger's syndrome (Table 2).

\section{Dysplastic and acquired forms of glomerulocystic kidney disease}

Glomerulocystic kidney disease also can be seen as a component of renal dysplasia (Fig. 3) and following significant fetal renal damage, such as that caused by maternal intake of drugs such as phenacetin [12], or following hemolytic uremic syndrome [13]. Tubular obstruction is postulated to play a role in the development of some forms of glomerulocystic kidney disease. This link to obstruction is not a simple relationship and appears to involve transcriptional reprogramming as well as changes in cilia length, as discussed below (Fig. 4).

\section{Specific genetic diseases associated with glomerulocystic kidney disease}

\section{Tuberous sclerosis complex}

Tuberous sclerosis complex (TSC) is a tumor suppressor syndrome associated with solid and cystic renal lesions. Glomerulocystic kidney disease associated with TSC was described almost 60 years ago [14] and is a well-
Fig. 1 An example of glomerulocystic disease in a child with autosomal dominant polycystic kidney disease. a Coronal section of a polycystic kidney, $\mathbf{b}$ histology demonstrating glomerular cysts (magnification $20 \times$ ). Note the normal-sized glomeruli with the enlarged Bowman's space and tubular cystic changes
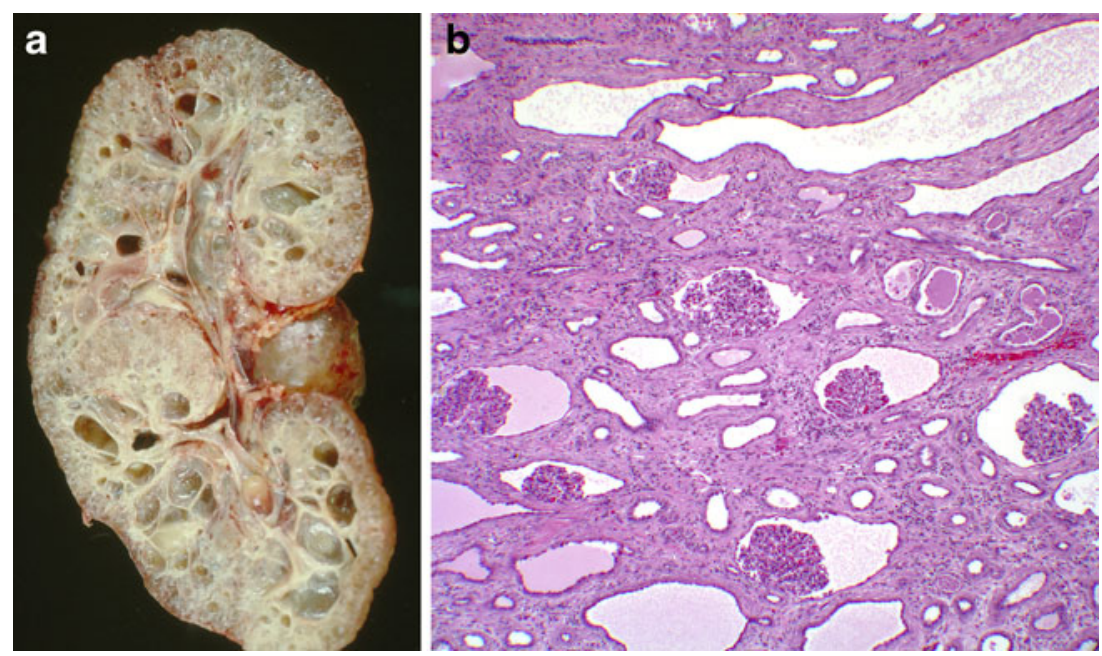
Fig. 2 An example of glomerulocystic disease in an infant with Meckel-Gruber syndrome. a Coronal section of the affected kidney, b histology demonstrating glomerular cysts (magnification $20 \times$ ). Note the fetal glomeruli and surrounding dysplastic tissue with tubular cystic changes
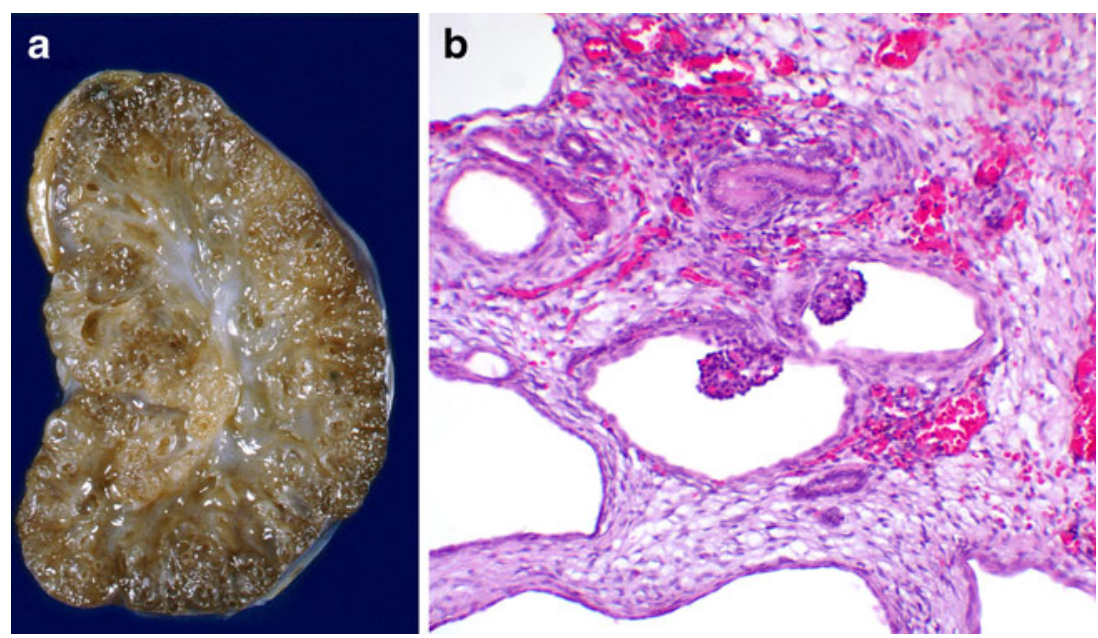

documented phenomenon $[5,15,16]$. In one study, among ten patients with TSC, four exhibited glomerulocystic kidney disease [16]. Only one of these patients was a teenager and the other three were infants. In each case, the glomerulocystic involvement was unilateral. The glomerular spaces exhibited large, bizarre parietal epithelial cells piled up against Bowman's capsule, and the glomerular tufts exhibited similarly atypical podocytes. The lining in the large cysts in TSC is also different from that in other renal cysts insofar as the epithelial cells are hypertrophic and hyperplastic with strongly eosinophilic cytoplasm [17, 18]. This type of hypertrophy is reminiscent of the phenotype seen in the eye cell of the Drosophila gigas mutant, which also lacks $T s c 2$ and cannot make tuberin [19]. The protein products of the TSC loci, the tumor suppressors tuberin and hamartin, function together to integrate cellular growth, nutritional, and energy status signals to gate cell growth and facilitate proliferation. Cellular loss of one of the TSC gene products results in constitutive activity of the mTORC1 growth pathway [20].

Table 2 Inherited and genetic malformation syndromes with glomerulocystic disease

\begin{tabular}{|c|c|c|}
\hline Syndrome & OMIM number $^{\mathrm{a}}$ & Disease reference \\
\hline Arthrogryposis-renal dysfunction-cholestasis (ARC) & \#208085 & {$[46]$} \\
\hline Brachymesomelia-renal syndrome & 113470 & [47] \\
\hline Cornelia de Lange syndrome & $\# 122470, \# 300590, \# 300590$ & [5] \\
\hline Congenital nephrotic syndrome Finnish type (microcystic disease) & \#256300 & [48] \\
\hline Down syndrome & \#190685 & [49] \\
\hline Asplenia with cardiovascular anomalies & $\% 208530$ & {$[50]$} \\
\hline Multiple acyl-CoA dehydrogenase deficiency & \#231680 & {$[51]$} \\
\hline Jeune's syndrome & $\% 208500$ & [5] \\
\hline Marden-Walker's syndrome & $\% 248700$ & [52] \\
\hline Maturity-onset diabetes of the young & \#606391 & {$[27,28,41,42]$} \\
\hline Meckel-Gruber syndrome & \#249000 & {$[26]$} \\
\hline Medullary cystic kidney disease & \#603860 & {$[24]$} \\
\hline Nephronophthisis & \#256100 & [53] \\
\hline Orofaciodigital syndrome-type I & \#311200 & [54] \\
\hline Phocomelia syndrome or Robert's syndrome (pscudothalidomide syndrome) & \#269000 & {$[5]$} \\
\hline Short-rib-polydactyly syndrome & $\% 263530, \% 263520$ & [55] \\
\hline Smith-Lemli-Opitz's syndrome & \#270400 & {$[5]$} \\
\hline Tuberous sclerosis complex & \#191100 & {$[5,14-16]$} \\
\hline Zellweger's cerebrohepatorenal syndrome & \#214100 & {$[56]$} \\
\hline
\end{tabular}

${ }^{a}$ OMIM numbering symbols: \#, indicates that a descriptive entry, often a phenotype, and does not represent a unique locus; \%, indicates a confirmed Mendelian phenotype or phenotypic locus for which the underlying molecular basis is unknown; no symbol, indicates a phenotypic description for which the Mendelian basis has not been clearly established or that the phenotype may also be in other entries 
Fig. 3 An example of glomerulocystic disease in a child with a multicystic dysplastic kidney. a Coronal section of a multicystic dysplastic kidney, b histology demonstrating glomerular cysts (arrow) and a focus of cartilage (asterisk) associated with the multicystic dysplastic kidney (magnification 20×)
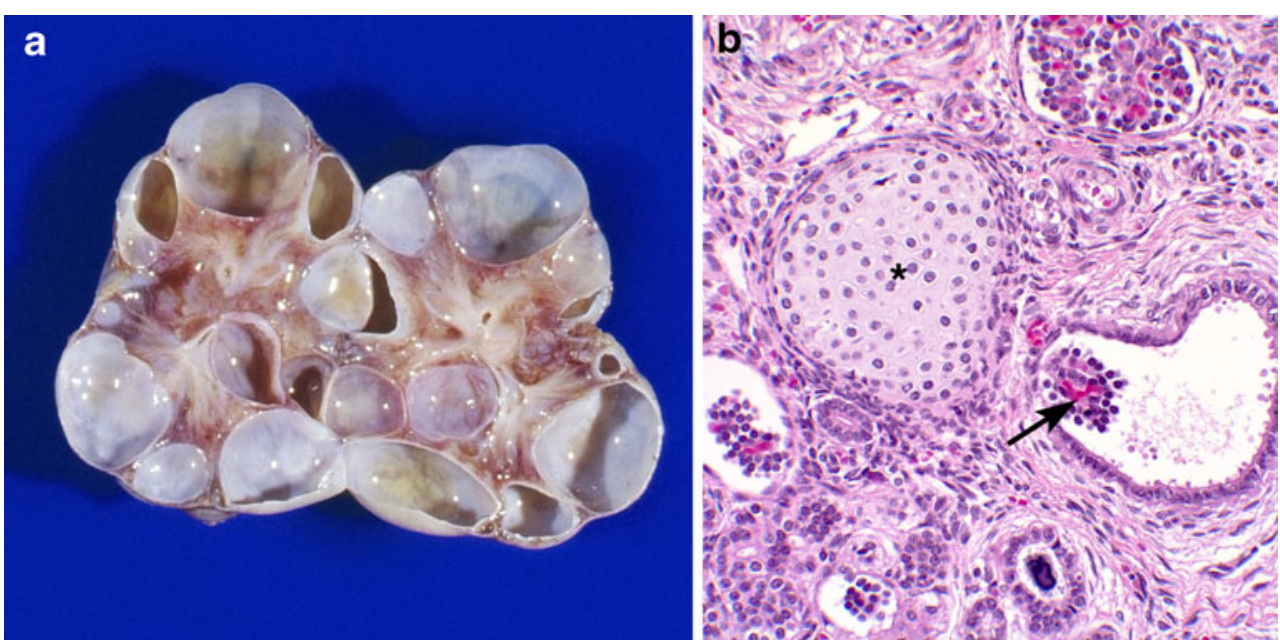

The TSC2 and PKD1 genes are adjacent on chromosome $16 \mathrm{p} 13$, and a contiguous germline deletion or mutation involving both genes results in a severe polycystic kidney phenotype at birth [21]. Children with this contiguous gene syndrome can be genetically mosaic; for example, DNA obtained from the peripheral white blood cells may show a different fraction of mutant allele when compared to DNA isolated from the kidney [21, 22]. The cystic disease can demonstrate rapid expansion, and the children can have very significant hypertension. This rapid progression may be due to developmental timing of the mutation [11] or its effects on the translation of critical genes. This latter possibility may also be compounded by RNA interference involving translation from the mutated alleles or possibly due to altered gene expression a result of the convergent transcription of genes on the unaffected allele [23]. Although the reason why these affected children have such an accelerated disease is unknown, the cellular morphology in the glomerular and medullary cysts provides strong evidence that the cysts are very unlike those found in ADPKD. The large size of the cells likely betrays the underlying defect in the mTORC1 signaling pathway for cell growth as well as the role of this pathway in renal development.

\section{Medullary cystic kidney disease}

Medullary cystic kidney disease (MCKD) type 2, familial juvenile hyperuricemic nephropathy, and glomerulocystic kidney disease are associated with mutations in the MCKD2 gene encoding uromodulin. Benetti et al. reported a family with an affected father and son. The son exhibited reduced bilateral kidney volumes, cortical hyperechogenicity, and two cysts in the left kidney, and the renal biopsy revealed the typical enlargement of Bowman's space with fibrosis and alpha actin positivity. At the corticomedullary junction, histological examination revealed immature tubules with cytokeratin and paired box gene 2 (PAX2)-positive immu-
Fig. 4 An example of glomerulocystic disease with obstruction. a Coronal section of a dysplastic kidney demonstrating a ureteropelvic junction obstruction, b histology demonstrating glomerulocystic disease (magnification 40×). Note the normal size of the glomerulus and dense interstitial lymphoplasmic infiltrate and tubular dilatation
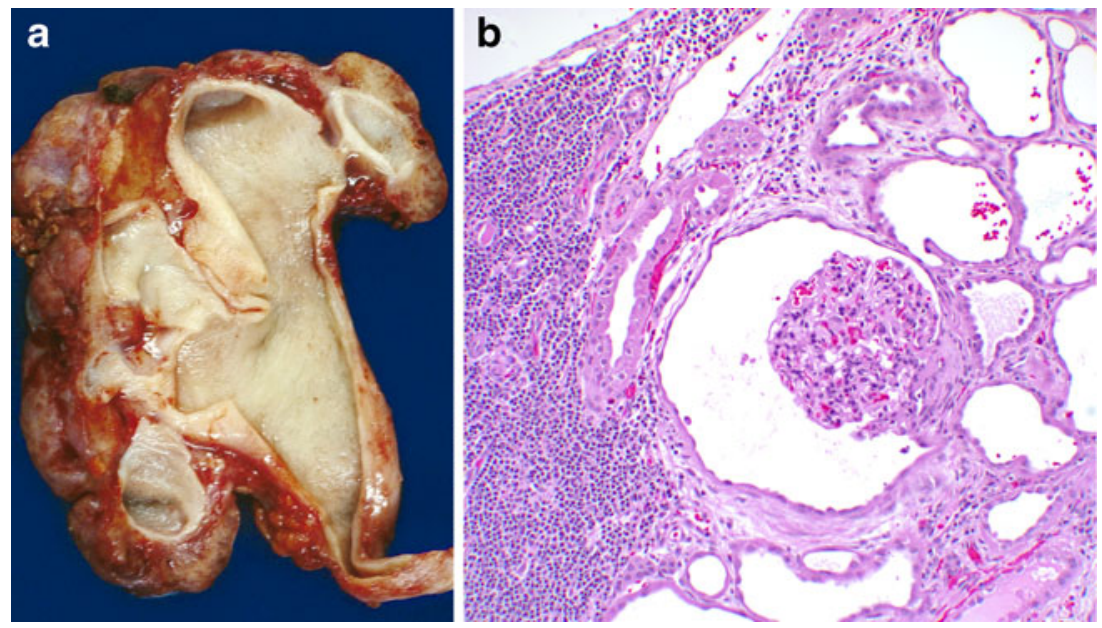
nostaining surrounded by vimentin-positive mesenchymal tissue. The patient did not excrete uromodulin, and a sequencing analysis showed a novel heterozygous sequence change in the UMOD gene [24]. Mutations in the MCKD2 gene often lead to earlier disease manifestation compared to mutations in the MCKD1 gene [25].

\section{Nephronophthisis}

Bergmann et al. studied a mouse model of nephronophthisis as well as families with the disease to understand the phenotypic spectrum of mutations in the NPHP3/Nphp3 gene and to garner insight into the functional role of the nephrocystin-3 protein [26]. The pcy mouse model results from a hypomorphic Nphp3 allele causing a slowly progressive renal cystic disease, while a complete loss of the locus function results in a more severe, multi-organ phenotype that includes situs inversus, congenital heart defects, and embryonic lethality.

The study of these families revealed that NPHP 3 mutations caused a broad clinical spectrum of early embryonic patterning defects that likewise resulted in situs inversus, polydactyly, central nervous system malformations, structural heart defects, preauricular fistulas, and a variety of congenital anomalies of the kidney and urinary tract. Importantly, the authors noted glomerulocystic kidney disease in at least one of the patients. There are numerous NPHP genes, but only the NPHP3 gene is currently associated with glomerulocystic disease. The authors further demonstrated that nephrocystin-3 directly interacted with another renal cystic kidney disease-related protein called inversin and that nephrocystin-3 inhibited the inversin-mediated canonical Wnt signaling. Wnt signaling is critical in renal development and has a role in renal cystogenesis. Wnt signaling occurs through the canonical and non-canonical pathways (Fig. 5), and switching between these pathways appears to be controlled by cilial deflection and cilioproteins. Using a Xenopus model, Bergmann et al. demonstrated that nephrocystin-3 deficiency led to planar cell polarity defects, supporting a role for nephrocystin-3 in the control of renal canonical and noncanonical Wnt signaling and establishing the importance of this pathway in renal cystic disease.

\section{Maturity-onset diabetes of the young}

Mutations in the gene encoding hepatocyte nuclear factor (HNF)-1 $\beta$ are associated with early-onset diabetes (maturity-onset diabetes in the young) and non-diabetic renal disease, including renal cystic disease. Bingham et al. sequenced the $H N F-1 \beta$ gene in four unrelated families with autosomal dominant glomerulocystic kidney disease and identified mutations in two families [27]. The protein

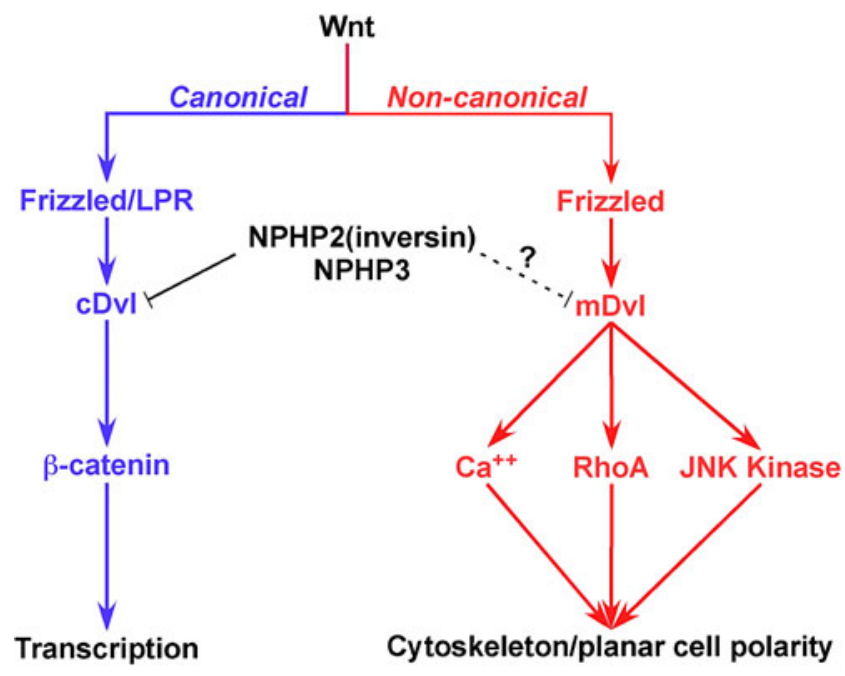

Fig. 5 Wnt signaling pathways. The canonical pathway is mediated through the cystoplasmic protein disheveled $(D v l)$ and ultimately effected through $\beta$-catenin-mediated transcription. The non-canonical pathway is mediated through membrane-bound Dvl and ultimately controls planar cell polarity. Inversin, the NPHP2 gene product, in concert with the NPHP3 protein, appears to facilitate development by controlling the Wnt pathway signaling. RhoA Ras homolog gene family, member A

product of this gene, HNF- $1 \beta$, is a widely expressed transcription factor that is critical for embryonic development of the kidney, pancreas, liver, and Mullerian duct. The affected families exhibited a dual phenotype that included hypoplastic glomerulocystic kidney disease and early-onset diabetes or impaired glucose tolerance. The authors concluded that there was genetic heterogeneity in familial glomerulocystic kidney disease and that the hypoplastic subtype was part of the clinical spectrum of the renal cysts and diabetes syndrome that are associated with $H N F-1 \beta$ mutations. Edghill et al. sequenced the $H N F-1 \beta$ gene in 160 unrelated subjects with renal cystic disease. Of these patients, only 64 had a personal or family history of diabetes mellitus. They identified 23 different heterozygous $H N F-1 \beta$ gene mutations. Despite the original association of the $H N F-1 \beta$ gene with diabetes, they emphasized the relationship to renal cystic disease, including glomerulocystic kidney disease [28].

\section{Mechanistic insights into glomerulocystic pathobiology}

Associations with the primary cilium

Glomerulocystic disease is an anatomically descriptive term and is associated with cystic disease syndromes, such as autosomal dominant and recessive polycystic kidney disease, maturity onset diabetes in the young, orofaciodigital syndrome, Bardet Biedl syndrome, and nephronophthi- 
Table 3 Ciliopathy-related renal disease

\begin{tabular}{|c|c|c|}
\hline Syndrome & Mutated gene & $\begin{array}{l}\text { Cilia/centrosome } \\
\text { references }\end{array}$ \\
\hline $\begin{array}{l}\text { Autosomal dominant } \\
\text { polycystic kidney } \\
\text { disease (ADPKD) }\end{array}$ & $\begin{array}{l}\text { PKD1 } \\
P K D 2\end{array}$ & {$[57]$} \\
\hline $\begin{array}{l}\text { Autosomal recessive } \\
\text { polycystic kidney } \\
\text { disease }\end{array}$ & PKHD1 & {$[58,59]$} \\
\hline Jeune & IFT80 & {$[60]$} \\
\hline Orofaciodigital (type 1) & $O F D 1$ & {$[61]$} \\
\hline Meckel-Gruber & $\begin{array}{l}\text { MKS1 } \\
\text { MSK3 }\end{array}$ & {$[62]$} \\
\hline Nephronophthisis & $\begin{array}{l}\text { NPHP1 } \\
\text { NPHP2 (inversin) } \\
\text { NPHP3 } \\
\text { NPHP4 } \\
\text { NPHP5 } \\
\text { NPHP6 } \\
\text { NPHP7 } \\
\text { NPHP8 (RPGRIPIL) } \\
\text { NPHP9 (NEK8) }\end{array}$ & {$[63]$} \\
\hline $\begin{array}{l}\text { Tuberous sclerosis } \\
\text { complex (TSC) }\end{array}$ & $\begin{array}{l}T S C 1 \\
T S C 2\end{array}$ & {$[64-67]$} \\
\hline Bardet-Biedl & $\begin{array}{l}B B S 1 \\
B B S 2 \\
B B S 3 / A R L 6 \\
B B S 4 \\
B B S 5 \\
B B S 6 / M K K S \\
B B S 7 \\
B B S 8 \\
B B S 9 \\
B B S 10 \\
B B S 11 / T R I M 32 \\
B B S 12\end{array}$ & [63] \\
\hline
\end{tabular}

sis, to name a few (Table 3 ). These syndromic renal cystic diseases are also associated with mutations in genes whose proteins are expressed in the renal tubular primary cilia or centrosome, and this association has lead to a 'unifying theory' of renal cystic disease involving these structures [29].

Primary cilia and the requisite centrosome are found in a variety of cells throughout the body where they serve a predominantly sensory role, including mechanosensation, chemosensation, and receptor-mediated signal transduction [30]. A recent comparative analysis of genomic and proteomic data sets enriched for basal body and ciliary proteins support the suggestion that the vertebrate cilium may require over 1000 different polypeptides [31]. These ciliary and basal body proteins are strongly linked to renal cystic disease as well as other cellular proliferationassociated diseases, including certain cancers [32]. The number of different proteins associated with cilia begins to shed light on the variety of signaling processes involved. Cilia facilitate signaling through the transient receptor potential (TRP) channels (notably polycystin-2) [33], the Wnt, hedgehog, and mitogen and growth factor pathways [30, 33-35]. Mouse models with disrupted cilia expression (Table 4) lead to a very clear glomerulocystic phenotype (Fig. 6), and cilia are expressed in parietal epithelial cells of Bowman's space (Fig. 7). The Wwtr transcription factor and Glis3, a cilia-related protein, have been shown to interact by co-immunoprecipitation and mammalian twohybrid systems, and dysfunction of the Glis3 or Wwtr1 signaling pathways results in aberrant gene regulation and the development of glomerulocystic kidney disease [36, 37].

Cilia are crucial for proper embryonic development. During development, the temporal and spatial expression of ciliopathy proteins are tightly controlled, and failure of proper expression can lead to renal cystic disease. Even non-renal manifestations can be explained on the basis of primary cilia; for example, eye findings are a logical extension of the nephronophthisis phenotype because ocular rods and cones are modified cilia. These critical cilial functions help explain the association of some renal cystic disease with such unusual features as retinal abnormalities and situs inversus [38]. The cilial involvement in development and the timing and extent of mutations may also impact the phenotypic expression of renal cystic disease. Glomerulocystic disease, at least in some cases of inherited cystic disease, is often identified in the very young patient, usually by ultrasound studies revealing increased renal cortical echogenicity. The timing of such glomerulocystic disease onset suggests that the pathogenesis may be developmentally regulated, as has been identified for certain murine models of renal cystic kidney disease [39]. In such a case, it is possible that disruptions in specific gene and signaling pathways at critical points during renal development could manifest in the glomerular region in a similar fashion to that of other regions of the kidney. Such temporal and spatial regulation may help explain the wide phenotypic variability of, for

Table 4 Mouse models of glomerulocystic disease

\begin{tabular}{lll}
\hline Mouse model & Gene & Reference \\
\hline pcy mouse & Nphp3 & {$[26]$} \\
Wwtr 1 mutant & Wwtrl & {$[36]$} \\
Glis3 mutant & Glis3 & {$[37]$} \\
$j c p k$ mouse & Biccl & {$[8]$} \\
Pkdl over expression & Pkdl & {$[68]$} \\
\hline
\end{tabular}




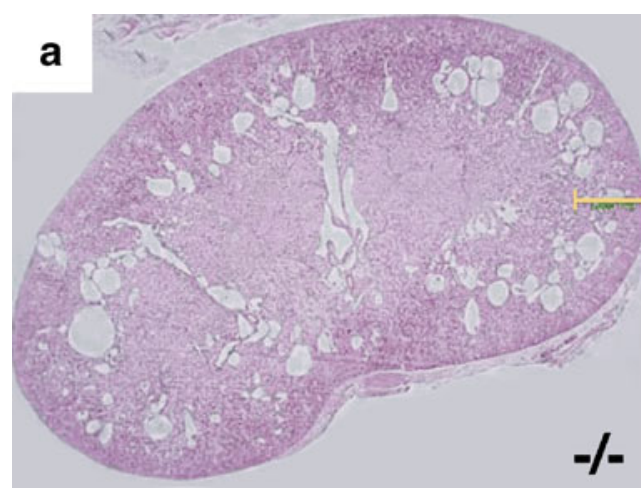

Fig. 6 Hematoxylin and eosin staining showing glomerulocystic disease in an 8-week old $W w t r l^{-/}$mouse. a Coronal kidney sections showing numerous cysts in the corticomedullary region of the kidney from the knockout mouse (magnification $20 \times$ ), b higher magnification

example, ADPKD, in which there can be significant pediatric involvement in the cases of very early onset disease and glomerulocystic disease, or geriatric onset disease.

Glomerulocystic disease associated with aberrant expression/signaling of HNF-1 $\beta$ may be indirectly related to primary cilia by virtue of recently described roles for the transcription factor in regulating the expression of certain cystoproteins that are expressed in cilia and in cilia-related cell signaling pathways. Hiesberger et al. recently demonstrated a role for HNF-1 $\beta$ in the transcription of the autosomal recessive polycystic kidney disease protein

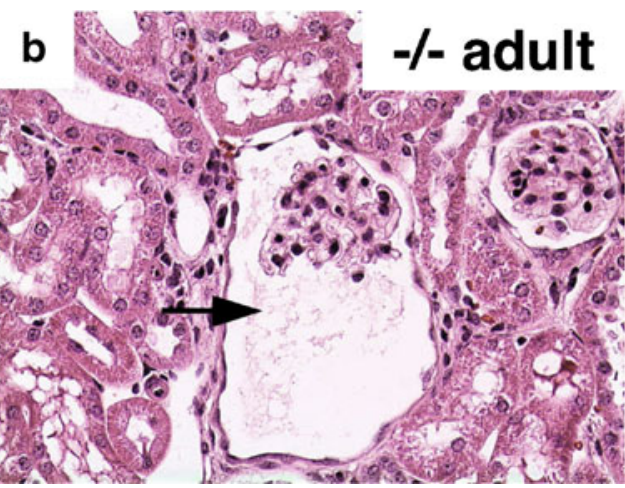

showing clear glomerulocystic disease with a reasonably normal glomerulus (arrow, magnification 40×). Modified with permission from [36]

PKHD1 [40]. Using a mouse model, these researchers identified an evolutionarily conserved HNF-1-binding site that mapped in a region of deoxyribonuclease hypersensitivity. They also demonstrated the binding of both HNF-1 $\beta$ and HNF- $1 \alpha$ to the $P k h d 1$ promoter and that this binding stimulated gene transcription. Transgenic mice expressing a dominant-negative HNF-1 $\beta$ controlled by a kidney-specific promoter developed renal cysts, and $P k h d 1$ transcripts were not expressed in the cells lining the cysts but were present in normal surrounding tubules. Gresh et al. also noted that renal-specific $H N F-1 \beta$ inactivation resulted in polycystic kidney disease, but they further observed a significant
Fig. 7 Immunohistological example of normal glomerular cilia. a Arrowheads indicate glomerular cilia on visceral and parietal epithelium, b magnification of cilia from a for a better visualization of the cilia. $\mathbf{c}$ Glomerular cilia; arrow depicts tubular cilia as a control, d magnification of cilia seen in $\mathbf{c}$. Images were obtained using a Zeiss Axiovert $200 \mathrm{M}$ microscope equipped with a $40 \times$ lens; acetylated alpha-tubulin 1:250, Alexa-488 chicken anti-mouse immunoglobulin G 1:250; nuclei stained with DAPI. Scale bar: $20 \mu \mathrm{m}$
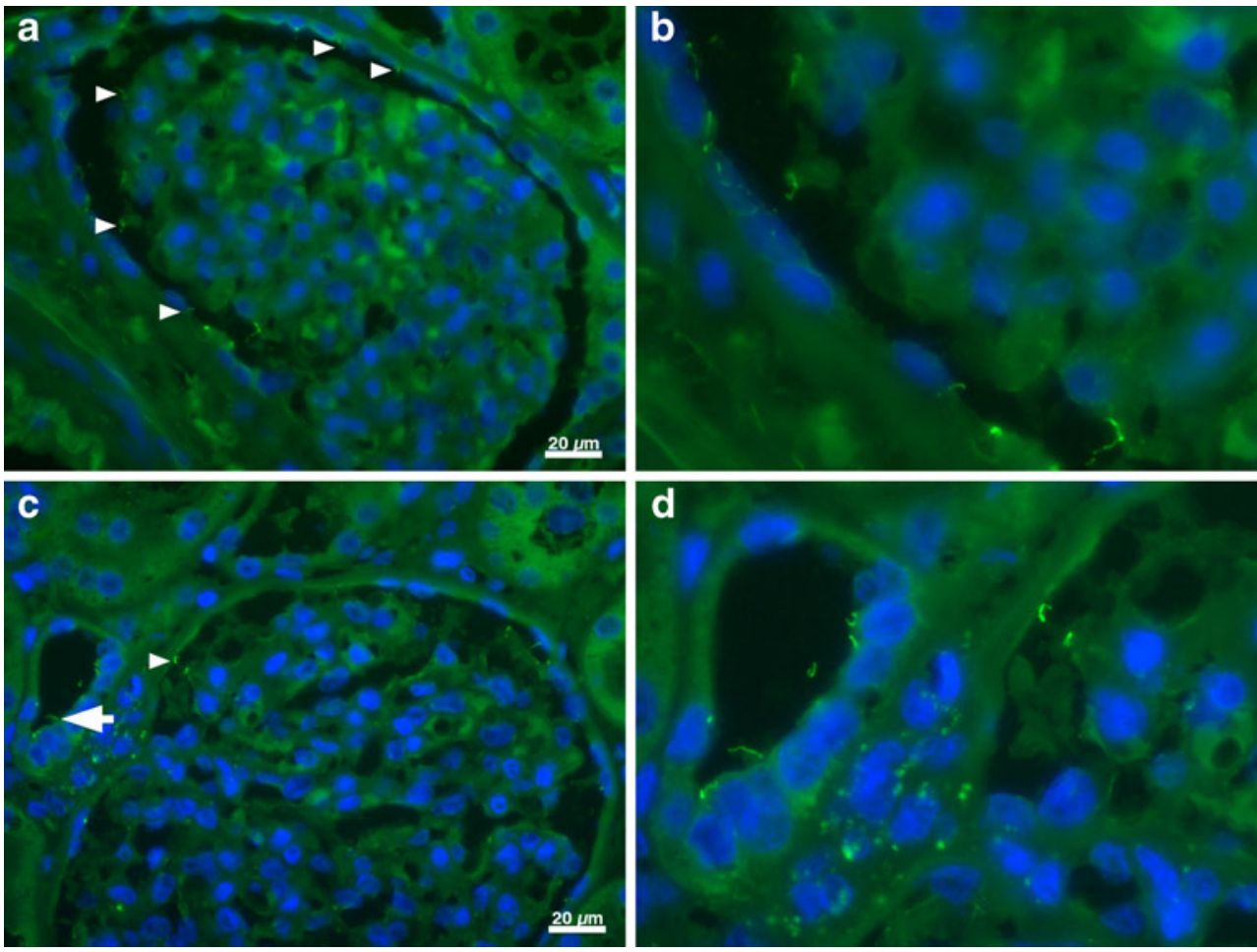
transcriptional defect in the Umod, $P k h d 1$, and $P k d 2$ genes. These three genes when mutated alone also lead to distinct cystic kidney syndromes [41]. Using immunoprecipitation, they identified that HNF-1 $\beta$ binds to several DNA elements in murine Umod, Pkhd1, Pkd2, and Tg737/Polaris genomic sequences, further asserting the link between HNF-1 $\beta$ and cystoproteins. The findings from these murine studies are compelling, but they do not indicate that the neonatal cystic disease is caused solely by reduced expression of these cystoproteins. Haumaitre et al. characterized two human fetuses with novel mutations, one in exon 2 and the other in exon 7 of the $H N F-1 \beta$ gene, that exhibited severe bilateral enlarged glomerulocystic kidneys, severe pancreas hypoplasia, and abnormal genital tracts. In contrast to the murine studies, a significant proportion of cysts expressed polycystin-1, polycystin-2, fibrocystin/polyductin complex, and uromodulin. The authors concluded that cyst formation in these cases may have resulted from a deregulation of cell-cell adhesion and/or the $\mathrm{Wnt} / \beta$-catenin signaling pathway. This contention was supported by the fact that the fetuses exhibited strongly down-regulated $\beta$-catenin and E-cadherin in the hypoplastic pancreas [42].

\section{Urinary tract obstruction}

The association of glomerulocystic kidney disease with renal dysplasia likewise may be rooted in transcription and developmental gene regulation. Renal malformations are often associated with urinary tract obstruction. Using an ovine model, Attar and colleagues unilaterally obstructed the ureter at a developmental point where only a few layers of glomeruli had formed and then characterized the renal development in the context of the un-obstructed kidney. They identified ureteric and pelvic dilatation and an increased renal parenchymal weight on the operated side compared to the contralateral organs or those from unoperated fetuses. The renal cortex on the obstructed side exhibited glomerulocystic disease [43]. The cystic epithelia strongly expressed $P A X 2$, a growth-stimulating transcription factor down-regulated during normal maturation. The cysts also exhibited increased cell proliferation and apoptosis, as had been previously reported in human kidney malformations. Dressler and Woolf described an association between renal cysts and increased $P A X 2$ expression [44]. One could speculate that the increased proliferation of cells would also be associated with a reduction in the number of primary cilia because the centriole cannot be involved in cytokinesis and cilia formation and maintenance at the same time. In light of these findings, it would be interesting to investigate the potential relationship between primary cilia and $P A X 2$ expression, particularly whether the persistence of $P A X 2$ expression beyond its developmental usefulness impacts proper cilia expression and signaling. Unilateral ureteral obstruction has also been shown to result in rather impressive changes in cilia morphology, supporting a link between cilia structure and function and glomerulocystic kidney disease [45].

\section{Conclusions}

The classification of glomerulocystic kidney disease has been almost exclusively descriptive up to this point in time, and for good reason. The different phenotypes are rare and associated with a wide array of additional features. Recent findings regarding gene and protein associations with some forms of glomerulocystic diseases have shed some light on the mechanisms that may underlie disease pathogenesis, indicating that primary cilia dysfunction may be involved. Based on current knowledge, the pivotal role of renal development in renal phenotypic cystic disease expression is to clarify the roles of developmental genes not only in cystogenesis but also ultimately in the link between renal cysts and renal neoplasms.

Acknowledgments Support for this manuscript was obtained from the Department of Defense (JJB) and the Polycystic Kidney Foundation (BJS).

\section{Questions}

(Answers appear following the reference list)

1. Which of the following statements about glomerulocystic kidney disease are true?

a. Glomerulocystic kidney disease can be associated with autosomal dominant polycystic kidney disease.

b. Glomerulocystic kidney disease can only be said to occur in otherwise normal kidneys.

c. Glomerulocystic kidney disease can be associated with tuberous sclerosis complex.

d. a and c.

e. $a, b$, and c.

2. Which statements about glomerulocystic kidney disease and ureteral obstruction are true?

a. Ureteral obstruction has been shown to be associated with glomerulocystic kidney disease.

b. Ureteral obstruction has an effect on $P A X 2$ expression.

c. Ureteral obstruction has an effect on cilia expression.

d. $a$ and $b$.

e. $a, b$, and $c$.

3. Which of the following statements about glomerulocystic kidney disease is false?

a. Glomerulocystic kidney disease is an anatomically descriptive term. 
b. Glomerulocystic kidney disease can be inherited as an autosomal dominant or recessive disorder.

c. Glomerulocystic kidney disease is associated with several different genetic loci.

d. Mouse models of glomerulocystic kidney disease do not resemble the human disease state.

e. Glomerulocystic kidney disease can be associated with changes in Wnt signaling.

4. Which of the following statements about glomerulocystic kidney disease is most true?

a. Glomerulocystic kidney disease can be associated with nephronophthisis.

b. Glomerulocystic kidney disease can be associated with medullary cystic kidney disease.

c. Glomerulocystic kidney disease can be associated with tuberous sclerosis complex.

d. Glomerulocystic kidney disease can be associated with maturity onset diabetes in the young.

e. All of the above are true.

5. Which of the following statements about glomerulocystic kidney disease is false?

a. Glomerulocystic kidney disease may manifest in some patients because of developmental timing effects.

b. Glomerulocystic kidney disease may manifest because of a change in ureteral patency.

c. Glomerulocystic kidney disease may develop because of changes in Wnt or hedgehog signaling.

d. Glomerulocystic kidney disease may develop following Henoch-Schönlein purpura.

e. Glomerulocystic kidney disease may develop following nephrotoxin exposure.

\section{References}

1. Roos A (1941) Polycystic kidney: report of a case studied by reconstruction. Am J Dis Child 61:116-127

2. Bialestock D (1960) Anaemia of renal origin, studied by microdissection of the kidney. Austr Annal Med 9:44-52

3. Baxter T (1965) Cysts arising in the renal corpuscle. Arch Dis Child 40:455-463

4. Taxy JB, Filmer RB (1976) Glomerulocystic kidney. Report of a case. Arch Pathol Lab Med 100:186-188

5. Bernstein J (1993) Glomerulocystic kidney disease-nosological considerations. Pediatr Nephrol 7:464-470

6. Gupta K, Vankalakunti M, Sachdeva MU (2007) Glomerulocystic kidney disease and its rare associations: an autopsy report of two unrelated cases. Diagn Pathol 2:12

7. Sharp CK, Bergman SM, Stockwin JM, Robbin ML, Galliani C, Guay-Woodford LM (1997) Dominantly transmitted glomerulocystic kidney disease: a distinct genetic entity. J Am Soc Nephrol 8:77-84

8. Flaherty L, Bryda EC, Collins D, Rudofsky U, Montogomery JC (1995) New mouse model for polycystic kidney disease with both recessive and dominant gene effects. Kidney Int 47:552-558

9. Lu W, Fan X, Basora N, Babakhanlou H, Law T, Rifai N, Harris PC, Perez-Atayde AR, Rennke HG, Zhou J (1999) Late onset of renal and hepatic cysts in $P k d 1$-targeted heterozygotes. Nat Genet $21: 160-161$

10. Lantinga-van Leeuwen IS, Leonhard WN, van der Wal A, Breuning MH, de Heer E, Peters DJ (2007) Kidney-specific inactivation of the $P k d l$ gene induces rapid cyst formation in developing kidneys and a slow onset of disease in adult mice. Hum Mol Genet 16:3188-3196

11. Patel V, Li L, Cobo-Stark P, Shao X, Somlo S, Lin F, Igarashi P (2008) Acute kidney injury and aberrant planar cell polarity induce cyst formation in mice lacking renal cilia. Hum Mol Genet $17: 1578-1590$

12. Krous HF, Richie JP, Sellers B (1977) Glomerulocystic kidney. A hypothesis of origin and pathogenesis. Arch Pathol Lab Med 101:462-463

13. Emma F, Muda AO, Rinaldi S, Boldrini R, Bosman C, Rizzoni G (2001) Acquired glomerulocystic kidney disease following hemolytic uremic syndrome. Pediatr Nephrol 16:557-560

14. Inglis K (1950) Neurilemmoblastomatosis. The influence of intrinsic factors in disease when development of the body is abnormal. Am J Pathol 26:521-549

15. Bernstein J, Robbins TO (1991) Renal involvement in tuberous sclerosis. Ann N Y Acad Sci 615:36-49

16. Bernstein J (1993) Renal cystic disease in the tuberous sclerosis complex. Pediatr Nephrol 7:490-495

17. Bernstein J, Meyer R (1967) Parenchymal maldevelopment of the kidney. In: Kelley V (ed) Brennemann-Kelley practice of pediatrics. Harper, New York, pp 1-30

18. Potter E (1952) Pathology of the fetus and the newborn. Year Book Medical, Chicago

19. Ferrus A, Garcia-Bellido A (1976) Morphogenetic mutants detected in mitotic recombination clones. Nature 260:425-426

20. Siroky BJ, Czyzyk-Krzeska MF, Bissler JJ (2009) Renal involvement in tuberous sclerosis complex and von Hippel-Lindau disease: shared disease mechanisms? Nat Clin Pract Nephrol 5:143-156

21. Brook-Carter PT, Peral B, Ward CJ, Thompson P, Hughes J, Maheshwar MM, Nellist M, Gamble V, Harris PC, Sampson JR (1994) Deletion of the TSC2 and PKD1 genes associated with severe infantile polycystic kidney disease-a contiguous gene syndrome. Nat Genet 8:328-332

22. Sampson JR, Harris PC (1994) The molecular genetics of tuberous sclerosis. Hum Mol Genet 3:1477-1480

23. Gullerova M, Proudfoot NJ (2008) Cohesin complex promotes transcriptional termination between convergent genes in $S$. pombe. Cell 132:983-995

24. Benetti E, Caridi G, Vella MD, Rampoldi L, Ghiggeri GM, Artifoni L, Murer L (2009) Immature renal structures associated with a novel UMOD sequence variant. Am J Kidney Dis 53:327331

25. Wolf MT, Mucha BE, Attanasio M, Zalewski I, Karle SM, Neumann HP, Rahman N, Bader B, Baldamus CA, Otto E, Witzgall R, Fuchshuber A, Hildebrandt F (2003) Mutations of the Uromodulin gene in MCKD type 2 patients cluster in exon 4, which encodes three EGF-like domains. Kidney Int 64:1580-1587

26. Bergmann C, Fliegauf M, Bruchle NO, Frank V, Olbrich H, Kirschner J, Schermer B, Schmedding I, Kispert A, Kranzlin B, Nurnberg G, Becker C, Grimm T, Girschick G, Lynch SA, Kelehan P, Senderek J, Neuhaus TJ, Stallmach T, Zentgraf H, Nurnberg P, Gretz N, Lo C, Lienkamp S, Schafer T, Walz G, Benzing T, Zerres K, Omran H (2008) Loss of nephrocystin-3 function can cause embryonic lethality, Meckel-Gruber-like syndrome, situs inversus, and renal-hepatic-pancreatic dysplasia. Am J Hum Genet 82:959-970

27. Bingham C, Bulman MP, Ellard S, Allen LI, Lipkin GW, Hoff WG, Woolf AS, Rizzoni G, Novelli G, Nicholls AJ, Hattersley AT (2001) Mutations in the hepatocyte nuclear factor-1beta gene are 
associated with familial hypoplastic glomerulocystic kidney disease. Am J Hum Genet 68:219-224

28. Edghill EL, Bingham C, Slingerland AS, Minton JA, Noordam C, Ellard S, Hattersley AT (2006) Hepatocyte nuclear factor-1 beta mutations cause neonatal diabetes and intrauterine growth retardation: support for a critical role of HNF-1beta in human pancreatic development. Diabet Med 23:1301-1306

29. Calvet JP (2003) Ciliary signaling goes down the tubes. Nat Genet 33:113-114

30. Veland IR, Awan A, Pedersen LB, Yoder BK, Christensen ST (2009) Primary cilia and signaling pathways in mammalian development, health and disease. Nephron Physiol 111:p39p53

31. Gherman A, Davis EE, Katsanis N (2006) The ciliary proteome database: an integrated community resource for the genetic and functional dissection of cilia. Nat Genet 38:961-962

32. Mans DA, Voest EE, Giles RH (2008) All along the watchtower: is the cilium a tumor suppressor organelle? Biochim Biophys Acta 1786:114-125

33. Siroky BJ, Ferguson WB, Fuson AL, Xie Y, Fintha A, Komlosi P, Yoder BK, Schwiebert EM, Guay-Woodford LM, Bell PD (2006) Loss of primary cilia results in deregulated and unabated apical calcium entry in ARPKD collecting duct cells. Am J Physiol Renal Physiol 290:F1320-F1328

34. Weimbs $T$ (2007) Polycystic kidney disease and renal injury repair: common pathways, fluid flow, and the function of polycystin-1. Am J Physiol Renal Physiol 293:F1423-F1432

35. Yoder BK (2007) Role of primary cilia in the pathogenesis of polycystic kidney disease. J Am Soc Nephrol 18:1381-1388

36. Hossain Z, Ali SM, Ko HL, Xu J, Ng CP, Guo K, Qi Z, Ponniah S, Hong W, Hunziker W (2007) Glomerulocystic kidney disease in mice with a targeted inactivation of Wwtr1. Proc Natl Acad Sci USA 104:1631-1636

37. Kang HS, Beak JY, Kim YS, Herbert R, Jetten AM (2009) Glis3 is associated with primary cilia and Wwtr1/TAZ and implicated in polycystic kidney disease. Mol Cell Biol 29:2556-2569

38. Ansley SJ, Badano JL, Blacque OE, Hill J, Hoskins BE, Leitch CC, Kim JC, Ross AJ, Eichers ER, Teslovich TM, Mah AK, Johnsen RC, Cavender JC, Lewis RA, Leroux MR, Beales PL, Katsanis N (2003) Basal body dysfunction is a likely cause of pleiotropic Bardet-Biedl syndrome. Nature 425:628-633

39. Piontek K, Menezes LF, Garcia-Gonzalez MA, Huso DL, Germino GG (2007) A critical developmental switch defines the kinetics of kidney cyst formation after loss of $P k d 1$. Nat Med 13:1490-1495

40. Hiesberger T, Bai Y, Shao X, McNally BT, Sinclair AM, Tian X, Somlo S, Igarashi P (2004) Mutation of hepatocyte nuclear factor1 beta inhibits $P k h d l$ gene expression and produces renal cysts in mice. J Clin Invest 113:814-825

41. Gresh L, Fischer E, Reimann A, Tanguy M, Garbay S, Shao X, Hiesberger T, Fiette L, Igarashi P, Yaniv M, Pontoglio M (2004) A transcriptional network in polycystic kidney disease. EMBO J 23:1657-1668

42. Haumaitre C, Fabre M, Cormier S, Baumann C, Delezoide AL, Cereghini S (2006) Severe pancreas hypoplasia and multicystic renal dysplasia in two human fetuses carrying novel HNF1beta/ MODY5 mutations. Hum Mol Genet 15:2363-2375

43. Attar R, Quinn F, Winyard PJ, Mouriquand PD, Foxall P, Hanson MA, Woolf AS (1998) Short-term urinary flow impairment deregulates $P A X 2$ and $P C N A$ expression and cell survival in fetal sheep kidneys. Am J Pathol 152:1225-1235

44. Dressler GR, Woolf AS (1999) Pax2 in development and renal disease. Int J Dev Biol 43:463-468

45. Wang L, Weidenfeld R, Verghese E, Ricardo SD, Deane JA (2008) Alterations in renal cilium length during transient complete ureteral obstruction in the mouse. J Anat 213:79-85
46. Arhan E, Yusufoglu AM, Sayli TR (2009) Arc syndrome without arthrogryposis, with hip dislocation and renal glomerulocystic appearance: a case report. Eur J Pediatr 168:995-998

47. Langer LO Jr, Nishino R, Yamaguchi A, Ito Y, Ueke T, Togari H, Kato T, Opitz JM, Gilbert EF (1983) Brachymesomelia-renal syndrome. Am J Med Genet 15:57-65

48. Sibley RK, Mahan J, Mauer SM, Vernier RL (1985) A clinicopathologic study of forty-eight infants with nephrotic syndrome. Kidney Int 27:544-552

49. Ariel I, Wells TR, Landing BH, Singer DB (1991) The urinary system in Down syndrome: a study of 124 autopsy cases. Pediatr Pathol 11:879-888

50. Ivemark B, Oldfelt V, Zetterstrom R (1959) Familial dysplasia of kidneys, liver, and pancreas: a probably genetically determined syndrome. Acta Pediatr Scand 48:1-11

51. Harkin JC, Gill WL, Shapira E (1986) Glutaric acidemia type II. Phenotypic findings and ultrastructural studies of brain and kidney. Arch Pathol Lab Med 110:399-401

52. Marden PM, Walker WA (1966) A new generalized connective tissue syndrome. Am J Dis Child 112:225-228

53. Tory K, Rousset-Rouviere C, Gubler MC, Moriniere V, Pawtowski A, Becker C, Guyot C, Gie S, Frishberg Y, Nivet H, Deschenes G, Cochat P, Gagnadoux MF, Saunier S, Antignac C, Salomon R (2009) Mutations of NPHP2 and NPHP3 in infantile nephronophthisis. Kidney Int 75:839-847

54. Feather SA, Winyard PJ, Dodd S, Woolf AS (1997) Oral-facialdigital syndrome type 1 is another dominant polycystic kidney disease: clinical, radiological and histopathological features of a new kindred. Nephrol Dial Transplant 12:1354-1361

55. Montemarano H, Bulas DI, Chandra R, Tifft C (1995) Prenatal diagnosis of glomerulocystic kidney disease in short-rib polydactyly syndrome type II, Majewski type. Pediatr Radiol 25:469-471

56. Kelley RI, Datta NS, Dobyns WB, Hajra AK, Moser AB, Noetzel MJ, Zackai EH, Moser HW (1986) Neonatal adrenoleukodystrophy: new cases, biochemical studies, and differentiation from Zellweger and related peroxisomal polydystrophy syndromes. Am J Med Genet 23:869-901

57. Watnick T, Germino G (2003) From cilia to cyst. Nat Genet $34: 355-356$

58. Ward CJ, Hogan MC, Rossetti S, Walker D, Sneddon T, Wang X, Kubly V, Cunningham JM, Bacallao R, Ishibashi M, Milliner DS, Torres VE, Harris PC (2002) The gene mutated in autosomal recessive polycystic kidney disease encodes a large, receptor-like protein. Nat Genet 30:259-269

59. Onuchic LF, Furu L, Nagasawa Y, Hou X, Eggermann T, Ren Z, Bergmann C, Senderek J, Esquivel E, Zeltner R, Rudnik-Schoneborn S, Mrug M, Sweeney W, Avner ED, Zerres K, Guay-Woodford LM, Somlo S, Germino GG (2002) PKHD1, the polycystic kidney and hepatic disease 1 gene, encodes a novel large protein containing multiple immunoglobulin-like plexin-transcription-factor domains and parallel beta-helix 1 repeats. Am J Hum Genet 70:1305-1317

60. Beales PL, Bland E, Tobin JL, Bacchelli C, Tuysuz B, Hill J, Rix S, Pearson CG, Kai M, Hartley J, Johnson C, Irving M, Elcioglu N, Winey M, Tada M, Scambler PJ (2007) IFT80, which encodes a conserved intraflagellar transport protein, is mutated in Jeune asphyxiating thoracic dystrophy. Nat Genet 39:727-729

61. Romio L, Wright V, Price K, Winyard PJ, Donnai D, Porteous ME, Franco B, Giorgio G, Malcolm S, Woolf AS, Feather SA (2003) OFD1, the gene mutated in oral-facial-digital syndrome type 1 , is expressed in the metanephros and in human embryonic renal mesenchymal cells. J Am Soc Nephrol 14:680-689

62. Khaddour R, Smith U, Baala L, Martinovic J, Clavering D, Shaffiq R, Ozilou C, Cullinane A, Kyttala M, Shalev S, Audollent S, d'Humieres C, Kadhom N, Esculpavit C, Viot G, Boone C, Oien C, Encha-Razavi F, Batman PA, Bennett CP, Woods CG, Roume J, Lyonnet S, Genin E, Le Merrer M, Munnich A, Gubler 
MC, Cox P, Macdonald F, Vekemans M, Johnson CA, Attie-Bitach T (2007) Spectrum of MKS1 and MKS3 mutations in Meckel syndrome: a genotype-phenotype correlation. Mutation in brief \#960. Online. Hum Mutat 28:523-524

63. Hildebrandt F, Attanasio M, Otto E (2009) Nephronophthisis: disease mechanisms of a ciliopathy. J Am Soc Nephrol 20:23-35

64. Kleymenova E, Ibraghimov-Beskrovnaya O, Kugoh H, Everitt J, Xu H, Kiguchi K, Landes G, Harris P, Walker C (2001) Tuberindependent membrane localization of polycystin-1: a functional link between polycystic kidney disease and the TSC2 tumor suppressor gene. Mol Cell 7:823-832

65. Dibella LM, Park A, Sun Z (2009) Zebrafish Tsc1 reveals functional interactions between the cilium and the TOR pathway. Hum Mol Genet 18:595-606

66. Weimbs $\mathrm{T}$ (2006) Regulation of mTOR by polycystin-1: is polycystic kidney disease a case of futile repair? Cell Cycle 5:2425-2429

67. Astrinidis A, Senapedis W, Henske EP (2006) Hamartin, the tuberous sclerosis complex 1 gene product, interacts with polo- like kinase 1 in a phosphorylation-dependent manner. Hum Mol Genet 15:287-297

68. Pritchard L, Sloane-Stanley JA, Sharpe JA, Aspinwall R, Lu W, Buckle V, Strmecki L, Walker D, Ward CJ, Alpers CE, Zhou J, Wood WG, Harris PC (2000) A human PKD1 transgene generates functional polycystin-1 in mice and is associated with a cystic phenotype. Hum Mol Genet 9:2617-2627

\section{Answers}

1. d.

2. e

3. d

4. e

5. d 